\title{
Potensi sumber bakteri resisten antibiotik berdasarkan kondisi kualitas air dan penggunaan lahan di Sungai Code, Yogyakarta: suatu tinjauan metodologis
}

\author{
M. P. Hadi ${ }^{* 1}$, L. N. Fadlillah ${ }^{2}$, M. Y. Widasmara ${ }^{3}$, W. I. Muziasari ${ }^{4}$, Subaryono ${ }^{1}$ \\ ${ }^{1}$ Pusat Studi Lingkungan Hidup, Universitas Gadjah Mada, Yogyakarta, Indonesia \\ 2Program Studi S3 Geografi Universitas Gadjah Mada, Yogyakarta, Indonesia \\ 3Program Studi Magister Perencanaan Pengelolaan Pesisir dan Daerah Aliran Sungai, Fakutas Geografi \\ Universitas Gadjah Mada, Yogyakarta, Indonesia \\ ${ }^{4}$ Department of Food and Environmental Sciences, University of Helsinki, Finlandia
}

\begin{abstract}
Abstrak.
Resistensi antibiotik merupakan ancaman utama terhadap kesehatan manusia. Penggunaan antibiotik tidak hanya dilakukan pada manusia, tetapi juga di bidang pertanian khususnya peternakan dan perikanan. Pengaturan penggunaan antibiotik pada peternakan dan perikanan tidak dapat dilakukan secara selektif, sehingga berpeluang terhadap terjadinya sebaran bakteri antibiotik ke alam bebas menjadi lebih masif. Bakteri ini dapat berubah dan mentransfer antibiotic resistant gene (ARG). Di Indonesia, data paparan ARG di alam bebas belum diketahui. Oleh karena itu, penelitian ini dilakukan, pada tulisan ini disajikan metode pendekatan yang digunakan dalam penelitian ARG, potensi sumber bakteri AR dan menganalisis parameter kualitas air yang berpengaruh terhadap AR. Sungai Code merupakan sungai ideal dari hulu ke hilir, yang diduga perairannya belum terjadi kontaminasi. Penggunaan lahan di DAS Code antara lain pertanian, peternakan, perikanan, perkotaan. Terdapat beberapa rumah sakit yang berpotensi sebagai sumber bakteri ARG. Sampel air diambil pada 13 titik untuk diuji BOD dan Bakteri Coli. Hasil dari penelitian tesebut diharapkan dapat diketahuinya potensi penyumbang antibiotik terbesar pada lingkungan terhadap antibiotik berdasarkan kondisi kualitas air dan penggunaan lahan. Metode ini juga dapat digunakan untuk evaluasi pengelolaan lingkungan.
\end{abstract}

Kata kunci: kualitas air, lingkungan, pengelolaan limbah, resistensi antibiotik

\begin{abstract}
.
Antibiotic resistance (AR) has become the major threat to human health. Using antibiotics drugs consistently for medication without knowing the exact regulation makes the bodies resistant toward antibiotic itself. The use of antibiotics not only for human, but it also use in agricultures and animals. The Regulation of using antibiotics nowadays only applied in human, whether using antibiotics for agricultural and animal farming has not been made. Hence, the spread of antibiotic resistant bacteria in environment is remarkable. This bacteria can transform and transfer the antibiotic resistant gene (ARG) to another bacteria. Based on this problem, WHO considered $A R$ as the three greatest threats to human health and lead consolidation to combat the AR. In Indonesia, the AR data is limited. This research aims to review methods use in AR's research, AR potential source and analyze several water quality that affect the $A R$ bacteria. . Code River is one of an ideal river which is believed has not been contaminated by AR. The dominant land use in Code River Basin are agriculture, animal farming, fishery, settlement. There are several hospitals in the river side which are potential as AR sources. The water samples were collected in 13 sites for BOD and E. Coli analysis. This research result were expected to provide comprehensive data of the potential AR sources in the environment based on the water quality and land use. This method can be used to evaluate environmental management program.
\end{abstract}

Keywords: water quality, environment, waste management, antibiotic resistance

\section{PENDAHULUAN}

Penyebaran gen resistensi antibiotik (antibiotic resistance gene/ARG) melalui bakteri saat ini merupakan hal yang menjadi perhatian di dunia global (Laport et al. 2016). Meskipun di negara-negara Skandinavia, penelitian

\footnotetext{
${ }^{*}$ Korespondensi Penulis

Email : mphadi@ugm.ac.id
} 
mengenai resistensi antibiotik sudah berkembang dan banyak dilakukan, secara global bakteri yang resisten terhadap antibiotik meningkat pada manusia dan hewan (Carlet et al. 2014). Di Indonesia, permasalahan mengenai resistensi antibiotik saat ini belum banyak diteliti dan dipahami oleh masyarakat. World Health Organization (WHO) menyatakan bahwa resistensi antibiotik merupakan ancaman global yang dapat merugikan baik dunia kesehatan maupun ekonomi (WHO 2014).

Siklus bakteri yang menyebabkan resistensi bakteri sudah terjadi secara alami di lingkungan sejak puluhan juta tahun yang lalu (Friedman et al. 2016). Proses evolusi bakteri rentan terhadap antibiotik dipicu oleh perilaku manusia dalam menggunakan antibiotik pada berbagai kegiatan, contohnya untuk pengobatan manusia dan hewan. Dampak dari penggunaan antibiotik tersebut dapat mengakibatkan tubuh menjadi rentan terhadap penyakit, apabila bakteri yang berkembang ditubuh sudah resisten terhadap antibiotik (Rather et al. 2017). Meningkatnya bakteri patogen manusia menimbulkan penyakit ringan seperti infeksi kandung kemih dan infeksi luka yang dapat menyebabkan kematian pada manusia, karena tubuh resisten terhadap antibiotik. Penyebab resistensi ini dapat berasal dari pola penggunaan antibiotik pada manusia dan hewan tanpa pengawasan, maupun dari bakteri yang masuk ke tubuh dari lingkungan bebas (Prigitano et al. 2017).

Permasalahan penyebaran bakteri yang resisten terhadap antibotik di lingkungan saat ini semakin meningkat. Hal ini disebabkan bakteri yang menjadi resisten karena perpindahan gen secara horisontal (horizontal gene transfer/ HGT). HGT menyebabkan penyebaran ARG semakin mudah dan melalui berbagai media di lingkungan, seperti di air, tanah, udara, makanan, dan makhluk hidup (Frieri et al. 2017). Telah ditemukan beberapa fakta yang menunjukkan resistensi terhadap antibiotik sangat besar keberadaannya di lingkungan. Memahami persebaran dari antibiotic resistance di lingkungan penting dilakukan untuk memprediksi persebaran bakteri yang resisten terhadap antibiotik di lingkungan terhadap bakteri yang tidak resisten terhadap antibiotik, termasuk manusia. Selain itu, meningkatkan kesadaran dan pengetahuan masyarakat mengenai antibiotic resistance penting dilakukan untuk mencegah persebaran dari antibiotic resistance tersebut.

Penelitian mengenai antibiotik di lingkungan masih jarang dilakukan di Indonesia. Sungai Code berada di Yogyakarta dinilai mewakili bermacammacam kegiatan dari hulu hingga hilir, seperti permukiman, pertanian, peternakan, rumah sakit, dan terdapat beberapa wilayah dengan kondisi masih alami. Kompleksitas yang ada pada Sungai Code menunjukkan bahwa wilayah tersebut juga rawan terhadap penyebaran gen resisten antibiotik melalui bakteri yang berasal dari sektor peternakan, limbah rumah tangga, dan limbah rumah 
sakit. Pengolahan limbah yang tidak sesuai dapat menimbulkan dampak negatif bagi lingkungan, salah satunya penyebaran ARG pada bakteri yang tidak terlihat secara kasat mata. Oleh karena itu, dibutuhkan penelitian yang komprehensif mengenai keberadaan dan persebaran bakteri resisten antibiotik di Indonesia, khususnya di Sungai Code. Berdasarkan data tersebut dapat dibuat profil resistensi antibiotik di lingkungan Indonesia. Tulisan ini membahas mengenai metode pendekatan yang digunakan dalam penelitian resistensi antibiotik, potensi sumber bakteri resisten antibiotik dan menganalisis parameter kualitas air yang berpengaruh terhadap potensi bakteri resisten antibiotik.

\section{METODOLOGI}

\subsection{Alat dan bahan}

Alat dan bahan yang digunakan dalam penelitian ini berupa water checker, botol sampel, pita ukur, water filtration apparatus, dan GPS (Global Positioning System).

\subsection{Penentuan lokasi pengambilan sampel kualitas air}

Lokasi pengambilan sampel kualitas air ditentukan dengan metode purposive sampling, yaitu menentukan sampel agar dapat mewakili variasi yang ada berdasarkan populasi yang ada.

Tabel 1. Lokasi potensial sumber bakteri antibiotik

\begin{tabular}{|c|c|c|}
\hline No & Lokasi & Kode \\
\hline 1 & Umbul Lanang (Mata air) & $1 \mathrm{~A}$ \\
\hline 2 & Umbul Wadon (Mata air) & $1 \mathrm{~B}$ \\
\hline 3 & $1 \mathrm{~km}$ dari Umbul Lanang & $1 \mathrm{C}$ \\
\hline 4 & Peternakan sapi & $2 \mathrm{~A}$ \\
\hline 5 & Pemotongan Ayam & $2 \mathrm{~B}$ \\
\hline 6 & Rumah Sakit (Inflow) & 3A-I \\
\hline 7 & Rumah Sakit (Outflow) & $3 A-0$ \\
\hline 8 & Sungai Utama setelah Limbah Rumah Sakit & $3 \mathrm{~A}-\mathrm{W}$ \\
\hline 9 & Jembatan Sayidan & $3 \mathrm{~B}$ \\
\hline 10 & Peternakan bebek & $2 \mathrm{C}$ \\
\hline 11 & Jembatan pertemuan Opak-Code & 2D \\
\hline 12 & Sebelum muara opak & $4 \mathrm{~A}$ \\
\hline 13 & Muara opak & $4 \mathrm{~B}$ \\
\hline
\end{tabular}

Titik sampel ditentukan berdasarkan masukan sumber pencemar penggunaan lahan, seperti limbah domestik. Sumber percemar khusus yang masuk ke sungai secara langsung juga diambil sebagai titik sampel, seperti limbah peternakan, limbah rumah sakit karena berpeluang sebagai sumber pencemar yang mengandung antibiotik. Jumlah sampel yang diambil sebanyak 12 sampel (Tabel 1). Peta titik sampel disajikan pada Gambar 1. 


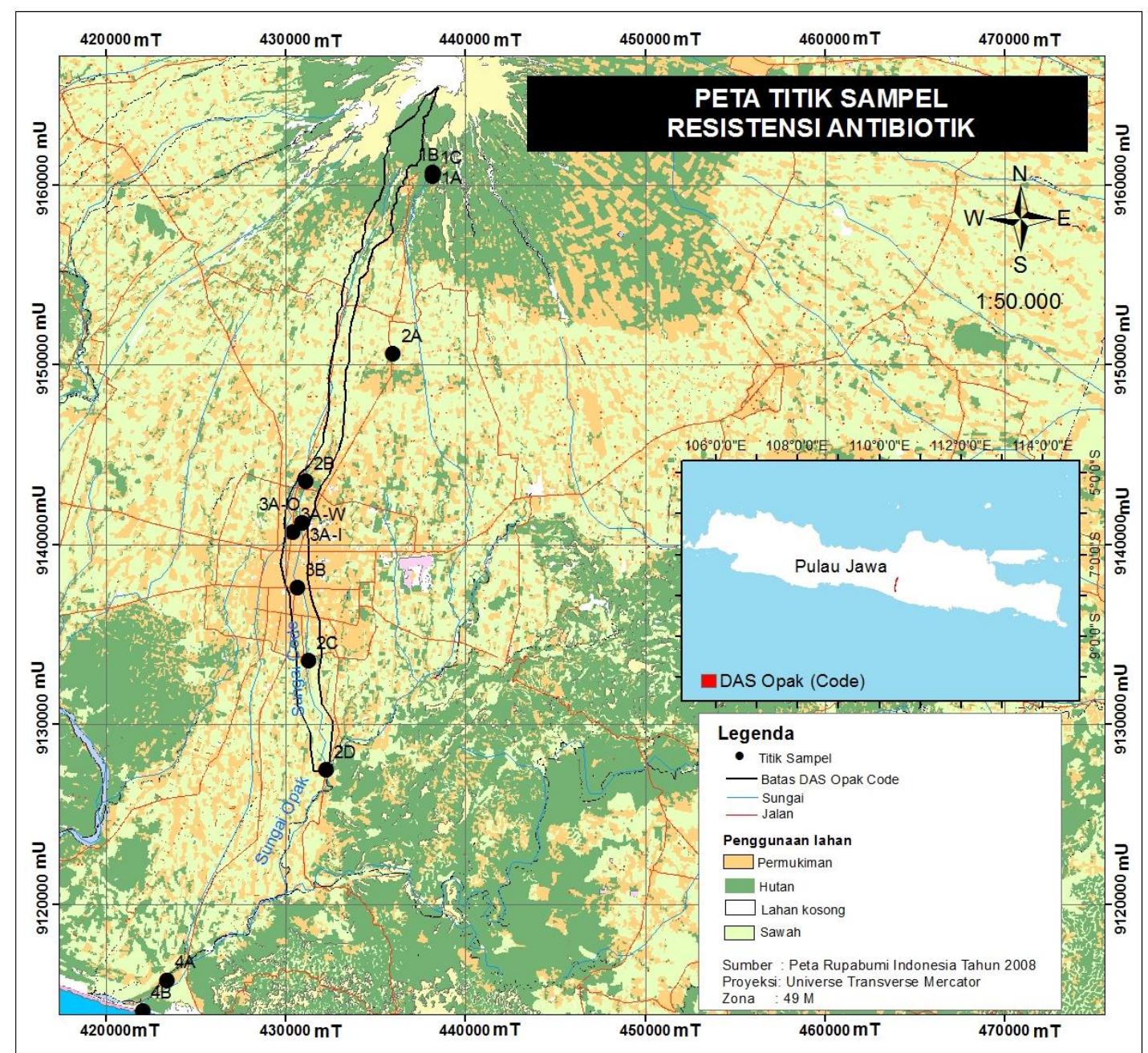

Gambar 1. Peta pengambilan sampel air dan sedimen.

\subsection{Karakteristik aliran}

Karakterisik aliran Sungai Code direpresentasikan pada titik pengamatan tinggi muka air sungai (papan duga) yang dipasang pada bagian tengah dari Sungai Code (Gemawang) (Gambar 2). Berdasarkan data debit aliran tahun 2013-2015, Sungai Code termasuk dalam kategori sungai perenial, yaitu sungai yang mengalir sepanjang tahun. Aliran air sungai tidak hanya berasal dari hujan tetapi juga suplai dari airtanah. Debit maksimum bulanan pada bulan Maret tahun 2014 sebesar $8,83 \mathrm{~m}^{3} / \mathrm{s}$, dan debit minimum sebesar $0,06 \mathrm{~m}^{3} / \mathrm{s}$. Tahun 2013, debit minimum terjadi pada bulan Agustus-November. Tahun 2014, debit minimum terjadi pada bulan April-November. Tahun 2015, debit minimum terjadi pada bulan Mei-November. Besarnya debit aliran pada sungai terkait kemampuan pengenceran pada beban pencemar yang masuk pada sungai. Pola 
debit aliran Sungai Code menunjukkan terjadi penurunan debit aliran dari tahun 2013-2015. Hal ini dapat disebabkan oleh kondisi klimatologis wilayah maupun jumlah wilayah resapan air yang semakin berkurang.

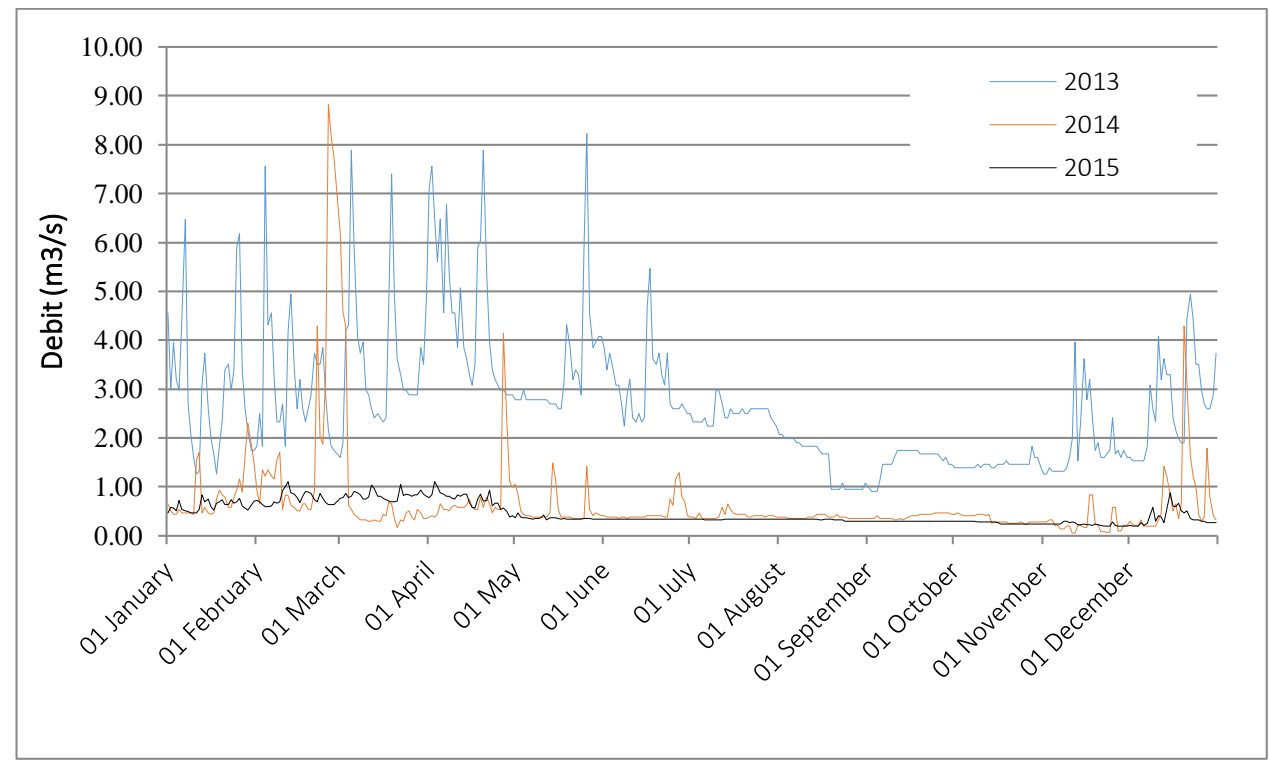

Gambar 2. Debit aliran Sungai Code (BBWS Serayu-Opak 2015).

\section{HASIL DAN PEMBAHASAN}

\subsection{Metode pengambilan sampel bakteri resisten antibiotik}

Metode yang diuraikan pada sub bab ini adalah metode yang direkomendasikan dalam penentuan bakteri resisten antibiotik pada air. Sampel yang diambil pada penelitian resistensi biotik terdiri dari sampel air dan sampel sedimen. Sampel air diambil untuk mengambil bakteri yang sedimen tersuspensi dalam sedimen. Jumlah total sampel air yang diambil adalah 1-2 liter bergantung kekeruhan air. Sampel air tersebut kemudian disaring dengan filter khusus bakteri (water filtration apparatus). Setiap lokasi diambil 3 botol pada lokasi yang berdekatan untuk validasi data dan uji statistik dan mengurangi kesalahan dari pengambilan data. Sampel sedimen diambil dari sedimen dasar sungai sebanyak 3-5 sendok makan. Setiap lokasi diambil 3 sampel sedimen. Sampel air dan sampel sedimen diawetkan dalam kotak pendingin. Sampel sedimen diawetkan dalam pendingin dengan suhu $-70^{\circ} \mathrm{C}$. Berdasarkan hasil penyaringan sedimen suspensi dan pengambilan sedimen dasar, ekstraksi DNA dilakukan dengan DNA isolation kit.

Analisa DNA pada dilakukan dengan $q P C R$ array, Smartchip realtime PCR system dari WaferGen. Hasil analisa tersebut diuji secara statistik dengan program R untuk membentuk profil resistensi antibiotik di lingkungan Indonesia 
(Muziasari et al. 2016). Wawancara secara insidental dilakukan untuk menggali informasi terkait sumber pencemar. Data karakteristik aliran diperoleh dari data sekunder dari instansi terkait.

Beberapa paremeter kualitas air memiliki hubungan terhadap keberadaan bakteri resisten antibiotic. Parameter kualitas air hasil uji laboratorium sebagai indikator utama adalah BOD (Biological Oxygen Demand). Analisis deskripstif komparatif digunakan untuk membandingkan kondisi kualitas air sungai daerah penelitian dengan standar baku mutu air menurut PP No. 82 Tahun 2001. Analisis korelasi antara kualitas air sungai dengan debit aliran digunakan untuk menggambarkan kondisi sumber pencemar secara temporal. Selain itu, juga dilakukan analisis mengenai keterkaitan antara kualitas air dengan keberadaan antibiotic resistance. Kota yang tercemar mempunyai risiko lebih besar terdapat adanya antibiotic resistance (Pal et al. 2016).

\subsection{Potensi sumber bakteri resisten antibiotik}

Penyebaran bakteri yang resisten terhadap antibiotik di lingkungan dapat berasal dari berbagai macam sumber, terutama rumah sakit, peternakan, dan perikanan. Hal ini disebabkan pada bidang tersebut penggunaan antibiotik dimungkinkan tidak terkontrol. Sektor-sektor tersebut dinilai menyumbangkan pengaruh terbesar karena penggunaan antibiotik pada manusia dan hewan (unggas dan ikan) yang sakit (Rather et al. 2017). Pengelolaan limbah dari rumah sakit umumnya sudah sesuai dengan standar Instalasi Pengelolaan Air Limbah (IPAL), namun perlu dilakukannya kontrol pada sungai sebagai tempat buangan akhir. Pada sektor perikanan dan peternakan, penggunaan antibiotik dilakukan untuk menyembuhkan ternak yang sakit. Penggunaannya dapat dikontrol apabila penggunaan antibiotik sesuai dengan resep dokter hewan.

Sungai Code merupakan sungai yang ideal, karena hampir satu garis dari hulu ke hilir. Sungai Code memiliki dua mata air yaitu Umbul Lanang dan Umbul Wadon yang terletak di kaki Gunung Merapi dan berhilir di Muara Opak. Mata air tersebut merupakan mata air kontak, karena pengaruh struktur geologi, yang keluar dari Lembah Sungai Code. Hasil analisis laboratorium masih dalam proses pengerjaan sehingga dalam paparan ini hanya menyampaikan metode pengambilan sampel bakteri antibiotik dan hubungannya dengan beberapa parameter kualitas air. Berdasarkan kondisi penggunaan lahan dan masukan sumber pencemar titik, terdapat 12 titik yang dapat digunakan sebagai lokasi sampling yang berpotensi sebagai sumber bakteri resistensi antibiotik dari hulu hingga hilir Sungai Code (Tabel 1).

Umbul Lanang (1A) dan Umbul Wadon (1B) merupakan titik kontrol atau titik utama, karena belum terpapar oleh sumber pencemar lain. Kualitas air pada kedua lokasi ini termasuk dalam golongan 1 , sehingga dapat diminum secara 
langsung. Cara pengambilan sampel adalah, sampel diambil langsung dari dalam mata air sebelum mengalir ke sungai. Kondisi penggunaan lahan sekitar adalah semak belukar. Titik $1 \mathrm{C}$ berada $1 \mathrm{~km}$ ke arah hilir setelah Umbul Wadon. Belum ada pengaruh manusia yang konstan, seperti permukiman. Sampel diambil sebelum bending. Kondisi penggunaan lahan sekitarnya adalah semak belukar dan banyak terdapat lumut.

Titik 2A merupakan keluaran dari peternakan sapi yang limbah buangannya adalah salah satu anak Sungai Code. Peternakan sapi menggunakan antibiotik sebagai vaksin dan obat apabila ternak sakit. Penggunaan lahan sekitar peternakan adalah permukiman. Limbah sudah diolah dengan IPAL sederhana. Pengolahan limbah peternakan dilakukan dengan mengendapkan kotoran dan membuang air limbah ke sungai. Titik 2B merupakan usaha pemotongan ayam. Sampel diambil pada keluaran limbah yang keluar dari lokasi pemotongan ini. Jumlah ayam yang dipotong perharinya sekitar 100-200 ekor. Tidak ada pengolahan limbah khusus sehingga limbahnya langsung mengalir ke sungai. Pengambilan sampel pada lokasi rumah pemotongan ayam dan peternakan dilakukan karena pada ayam potong biasa dilakukan penyuntikan obat untuk penggemukan dan vaksin hewan (Prigitano et al. 2017).

Sampel air pada limbah rumah sakit diambil pada masukan (inflow) IPAL (3A-I) dan keluaran (outflow)(3A-0). Limbah rumah sakit sudah diolah dengan IPAL metode lumpur aktif and dikontrol dengan bioindikator berupa ikan. Sebagai titik kontrol pengaruh limbah rumah sakit yang masuk ke sungai dilakukan pengambilan sampel setelah keluaran IPAL rumah sakit ke Sungai Code (3A-W). Titik 3B diambil di Sungai Code di daerah Kota Yogyakarta. Penggunaan lahan dominan adalah permukiman. Lokasi tersebut dipilih karena banyak limbah domestik yang dibuang langsung ke sungai. Potensi resistensi antibiotik dapat berasal dari urin masyarakat yang dibuang tanpa pengolahan.

Sampel 2C diambil pada lokasi keluaran limbah pada lokasi peternakan itik yang secara langsung membuang limbahnya ke Sungai Code. Tidak ditemukan informasi terkait pengolahan limbah pada peternakan itik tersebut. Kondisi penggunaan lahan sekitar adalah permukiman. Titik 2D merupakan titik pertemuan antara Sungai Code dan Sungai Opak, sebelum akhirnya bergabung menjadi Sungai Opak, Titik Sampel diambil pada Sungai Opak sebelum bertemu Sungai Code sebagai kontrol pengaruh Sungai Code ke Sungai Opak. Titik 4A diambil di Sungai Opak sebelum estuari, sebagai kontrol kondisi sebelum bercampur dengan air laut. Titik 4B merupakan titik pada muara sungai. Diambil untuk mengetahui pengaruh laut dan potensi keberadaan gen rensistensi antibiotik setelah tertransport dari hulu ke hilir. 


\subsection{Kondisi kualitas air}

Aktivitas penduduk yang berkembang pesat di wilayah DAS Sungai Code mempengaruhi kualitas air Sungai Code. Berbagai macam sumber pencemar yang berpotensi mencemari lingkungan, yaitu aktivitas permukiman (domestik), pertanian, peternakan, dan perikanan. Peningkatan aktivitas tersebut berdampak buruk terhadap kualitas air sungai. Pencemaran terjadi ketika kualitas air sungai melebihi baku mutu air yang telah ditetapkan. Parameter yang digunakan dalam kajian ini adalah BOD dan jumlah coliform. Parameter BOD cenderung sensitif terhadap pencemaran, hal ini terkait dengan prosesproses biologis (khususnya mikroorganisme dalam air). Parameter coliform digunakan untuk menunjukan sumber Escherichia coli yang berasal dari manusia dan ternak. Parameter kualitas air tersebut menggambarkan kondisi kualitas air secara umum, sedangkan untuk membedakan bakteri yang sama dari sumber yang berbeda melalui analisis Antibiotic Resistance Analysis (Stoeckel 2005).

Keberadaan antibiotic resistance sangat erat kaitannya dengan perkembangan daerah. Daerah yang tercemar mempunyai potensi lebih besar terpapar antibiotic resistance ( $\mathrm{Pal}$ et al. 2016). Beberapa analisis pencemaran air, menunjukan 64\% BOD berasal dari limbah domestik (World bank 2013), dimana keberadaan antibiotic resistance dominan berasal dari sisa buangan (ekskresi) manusia (Berendonk et al. 2015; Matinez 2008). BOD menggambarkan jumlah oksigen yang digunakan untuk menguraikan bahan organik. Kadar BOD yang tinggi, menunjukan bahwa jumlah bahan organik yang terdapat pada perairan cenderung tinggi. Berdasarkan parameter BOD menandakan bahwa Sungai Code tercemar, karena kadarnya melebihi baku mutu air kelas II sesuai dengan PP No 82 Tahun 2011.

Terdapat 8 titik pengamatan kualitas air pada penelitian. BOD pada masing-masing diukur setiap bulan Februari (I), Juni (II), dan Oktober (III) (Tabel 2; Gambar 3). Waktu pengukuran tersebut merepresentasikan kondisi debit aliran pada saat musim penghujan dan kemarau. Sumber pencemar setiap titik pangamatan cenderung bervariasi. Hal ini diidentifikasi berdasarkan jenis aktivitas yang dominan. Aktivitas pertanian direpresentasikan oleh titik pengamatan 2 dan 8, vegetasi alami dan peternakan ditunjukan oleh titik pengamatan 1. Aktivitas peternakan yang dominan di daerah tersebut adalah peternakan Sapi yang berada di Kecamatan Pakem, Sleman. Tidak semua aktivitas peternakan di daerah tersebut menggunakan IPAL (Instalasi Pengolahan Air Limbah). Aktivitas manusia berupa kegiatan domestik, rumah sakit, dan industri (percetakan) direpresentasikan oleh titik pengamatan kualitas air dari titik 3-7. 
Tabel 2. Lokasi pengamatan kualitas air sungai code.

\begin{tabular}{cll}
\hline No & \multicolumn{1}{c}{ Lokasi Pengamatan } & \multicolumn{1}{c}{ Sumber Pencemar Dominan } \\
\hline 1 & Jembatan Boyong Pakem, Sleman & Vegetasi alami, peternakan \\
2 & Jembatan Ngentak, Sariharjo, Ngaglik, Sleman & Pertanian \\
3 & Jembatan Gondolayu, Jetis, Yogykarta & Permukiman \\
4 & Jembatan Gondomanan, Yogyakarta & Permukiman \\
5 & Jembatan Keparakan, Mergangsan, Yogyakarta & Permukiman \\
6 & Jembatan Tungkak, Mergangsan, Yogyakarta & Permukiman \\
7 & Jembatan Abang Ngoto, Sewon, Bantul & Permukiman \\
8 & Jembatan Pacar Wonokromo, Pleret Bantul & Pertanian \\
\hline
\end{tabular}

Tahun 2013, BOD cenderung tinggi pada sumber pencemar peternakan dan permukiman dan pada bulan pengamatan III. Pada tahun 2014, konsentrasi BOD cenderung tinggi pada bulan pengukuran II. Tahun 2015, nilai BOD cenderung tinggi pada bulan pengukuran ke III. Pada tahun 2016 limbah dari peternakan dan permukiman kandungan BOD cenderung tinggi dan secara temporal tidak ada variasi yang cukup signifikan. Hal ini terkait dengan debit aliran pada Sungai Code. Semakin besar debit aliran pada sungai, maka kemampuan self purification melalui proses pengenceran akan semakin besar (Tian et al. 2011). Tahun 2014, pada bulan Juni terjadi debit minimum (Gambar 1), sehingga konsentrasi BOD pada bulan tersebut cenderung tinggi.

Berdasarkan Gambar 3, nilai BOD Sungai Code cenderung bervariasi secara spasial maupun temporal. Secara umum, kondisi kualitas air Sungai Code termasuk dalam klasifikasi tercemar atau tidak sesuai dengan peruntukannya, karena nilai konsentrasi BOD yang melebihi batas baku mutu BOD kelas II (3 $\mathrm{mg} / \mathrm{l})$.

Gambar 4 menunjukkan konsentrasi total coliform di Sungai Code pada beberapa tahun. Total coliform merupakan parameter kualitas air sebagai indikator bakteri yang digunakan untuk menentukan tingkat keamanan air untuk dikonsumsi. Hal ini terkait dengan bakteri patogenik yang terdapat pada perairan seperti Gardia dan Cryptosporidium. Semakin tinggi jumlah total coliform pada badan air, maka semakin tinggi pula potensi adanya antibiotic resistance. Metode analisis antibiotic resistance dapat diketahui sumber-sumber bakteri dalam perairan (Shank, 2005). Jumlah coliform dalam air diatur menurut baku mutu kelas air, untuk identifikasi pencemaran. Untuk air minum diatur menggunakan Kepmenkes RI No. 907/Menkes/VII/2002, dengan kadar minimum bakteri adalah 0 JPT/100 ml. Untuk keperluan air minum, jumlah bakteri tidak diperbolehkan/diizinkan. Keberadaan bakteri sangat berbahaya bagi kesehatan manusia.

Jenis-jenis bakteri yang resisten berasal dari limbah manusia, binatang, maupun pengaruh eksternal lingkungan. Total coliform menunjukkan jumlah bakteri dalam badan air. Dalam Gambar 4, jumlah bakteri cenderung banyak 
pada periode ke I (Februari). Berdasarkan data debit aliran, pada bulan Februari debit air Sungai Code cenderung tinggi. Secara keruangan, konsentrasi total coliform cenderung tinggi pada jenis sumber pencemar permukiman. Adanya limbah domestik dan ternak pada jenis penggunaan lahan permukiman. Jenis aktivitas tersebut mempunyai gen resisten yang berbeda pula. Seperti tentracyclines berasosiasi dengan gen resisten dari hewan dan gen resisten betalactam cenderung tinggi dari lingkungan eksternal (Pal et al. 2016). Identifikasi terhadap jenis gen resisten penting untuk strategi pengelolaan sumberdaya air sungai.

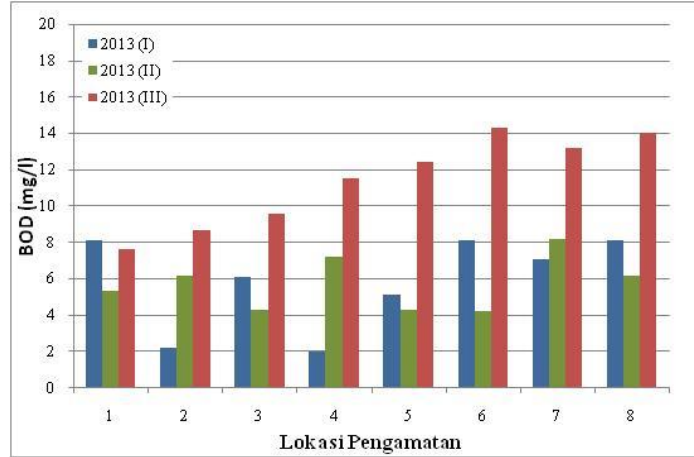

A

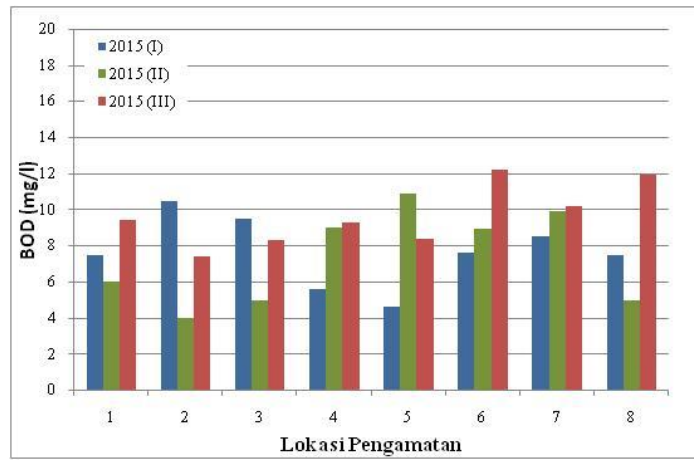

C

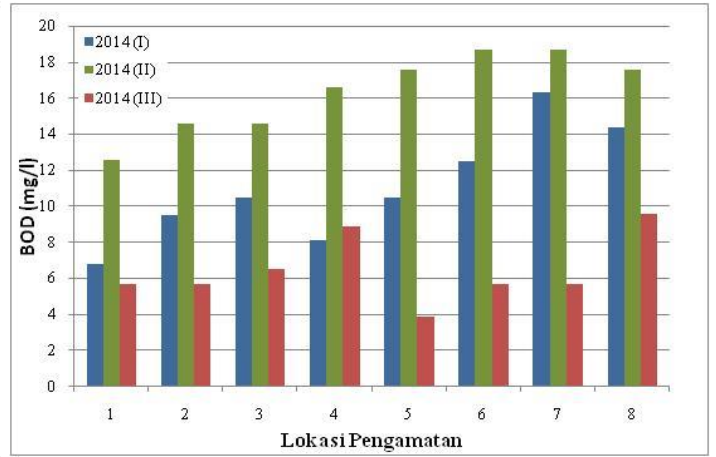

B

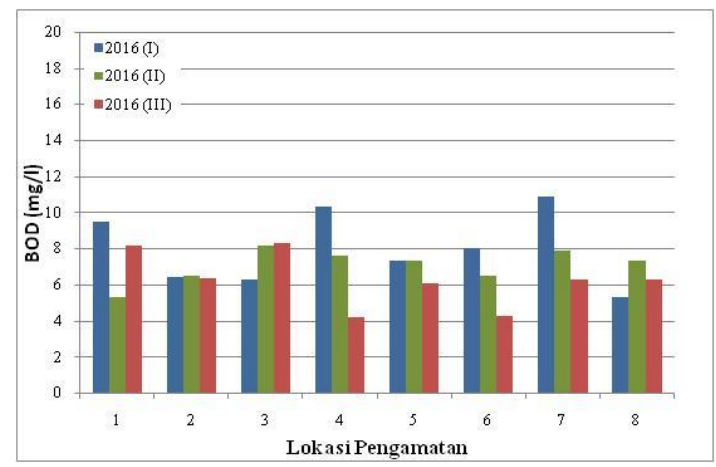

D

Gambar 3. Konsentrasi BOD Sungai Code Tahun 2013 (A), 2014 (B), 2015 (C), 2016 (D). 


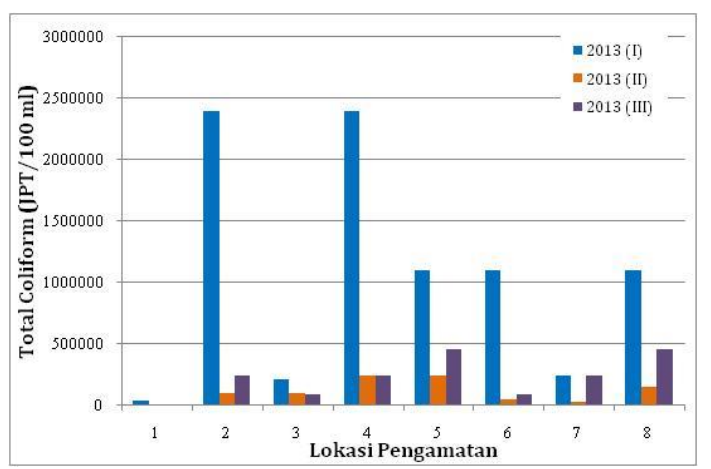

A

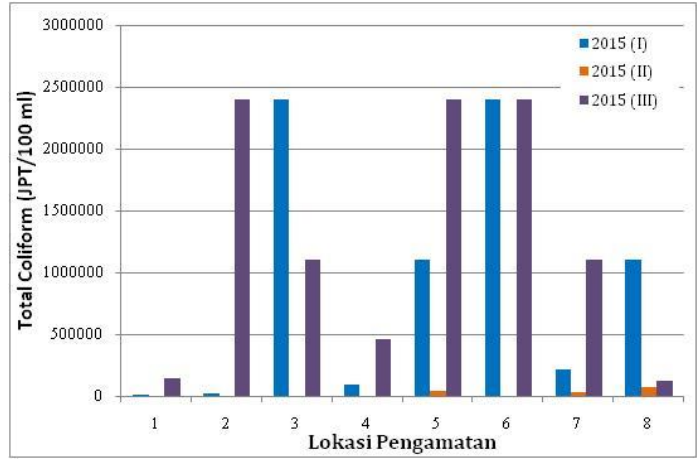

C

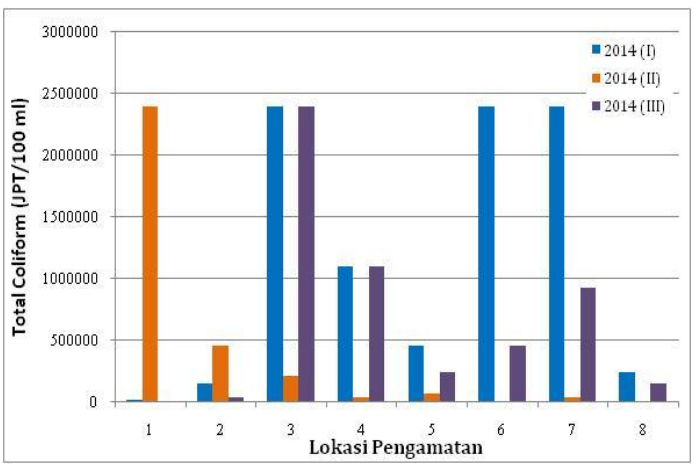

B

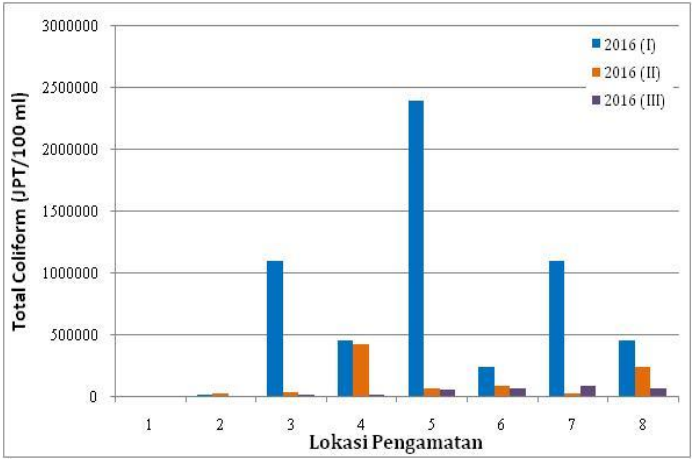

D

Gambar 4. Konsentrasi total coliform Sungai Code Tahun 2013 (A), 2014 (B), 2015 (C), 2016 (D) DI Yogyakarta.

\subsection{Pengendalian resistensi antibiotik}

Dampak dari penyebaran antibiotik adalah meningkatnya resistensi pada tubuh manusia dan hewan yang secara langsung dapat menyebabkan peningkatan mortalitas dan morbiditas. Efek resistensi antibiotik secara ekonomi adalah lamanya masa perawatan sehingga meningkatkan biaya perawatan di rumah sakit (Negara 2014). Pemerintah Indonesia saat ini menyadari dampak dari resistensi antibotik dengan dikeluarkannya Peraturan Menteri Kesehatan Republik Indonesia (Kepmenkes RI) Nomor 8 Tahun 2015 tentang Program Pengendalian Resistensi Antimikroba di Rumah Sakit. Pada peraturan tersebut dijelaskan bahwa penggunaan antibiotik harus dilakukan dengan pemahaman dan terkendali dalam lingkungan rumah sakit. Kondisi ini didukung oleh kebijakan Obat Nasional dalam Peraturan Menteri Kesehatan RI No 2406/MENKES/PER/2011 tentang Pedoman Umum Penggunaan Antibiotik dan Pedoman Pelayanan Kefarmasian untuk terapi antibiotik.

Cara-cara ini merupakan tindakan pengendalian pada tingkat pemerintahan melalui kebijakan-kebijakan yang berdampak ke pada publik (Carlet et al. 2014). Melalui peraturan tersebut pembelian antibiotik secara 
bebas sangat ditekan di Apotek. Untuk mengoptimalkan pengendalian dan monitoring penggunaan antibiotik, sosialisasi kepada masyarakat melalui dinas, puskesmas, posyandu, LSM, dan lembaga kemasyarakatan lainnya perlu dilakukan, karena budaya meminum obat tanpa resep dokter di masyarakat saat ini masih tinggi (Rather et al. 2017).

\section{KESIMPULAN DAN SARAN}

Resistensi Antibiotik merupakan ancaman yang belum disadari oleh sebagian masyarakat. Penyebaran resistensi antibiotik di lingkungan dapat berasal dari air, tanah, udara, maupun makhluk hidup. Sungai Code memiliki potensi penyebaran antibiotik dari berbagai sumber, diantaranya peternakan, limbah domestik, dan rumah sakit. Pengendalian antibiotik dalam ranah rumah sakit sudah dapat dilakukan. Namun, pengendalian resistensi antibotik secara umum masih sulit dilakukan karena kurangnya pengetahuan masyarakat dalam menggunakan obat dan mengolah limbah, serta dampaknya terhadap makhluk hidup dan lingkungan. Bakteri coli merupakan salah bakteri yang potensial sebagai patogen pembawa gen resisten terhadap antibiotik. Kecenderungan Sungai Code menunjukkan coli tinggi berasal dari penggunaan lahan permukiman. Nilai Coli tinggi pada saat musim hujan.

\section{UCAPAN TERIMA KASIH}

Pada kesempatan ini penulis mengucapkan terima kasih kepada PSLH-UGM yang telah mendukung penelitian ini. Juga kepada Prof. Marko Virta University of Helsinki, dan Prof Iwan P., yang telah memberi dukungan dalam program kerjasama UGM-University of Helsinki, Finlandia.

\section{Daftar Pustaka}

Berendonk TU, Manaia CM, Merlin C, Fatta-Kassinos D, Cytryn E, Walsh F, Burgmann H, Sorum H, Norstrom M, Pons M, Kreuzinger N, Huovinen P, Stefani S, Schwartz T, Kisand V, Baquero dan Martinez FJL. 2015. Tackling antibiotic resistance: the environmental framework. Nature Review Microbiology 13:310-317.

Carlet J, Pulcini C and Piddock LJ. 2014. Antibiotic resistance: a geopolitical issue. Microbial Infect 20(10):949-953.

Friendman ND, Temkin E and Carmeli Y. 2016. The negative impact of antibiotic resistance. Microbial Infect 22(5): 416-422.

Frieri M, Kumar K and Boutin A. 2017. Antibiotic resistance. Journal of Infection and Public Heath 10: 369-378.

Keputusan Menteri Kesehatan Republik Indonesia Nomor 907 Tahun 2002 tentang syarat-syarat dan pengawasan kualitas air minum. 
Laport MA, Pontes PVM, Santos DSd, Santos-Gandelman JF, Muricy G, Bauwens M, de Marvel MG and George I. 2916. Antibiotic genes detected in the marine sponge petrimica citriba from Brazilian Coast. Brazilian Journal of Microbilogy 47:617-620.

Martinez JL. 2008. Antibiotics and antibiotic resistance genes in natural environments. Science. 321:365-367.

Muziasari WI, Parnanen K, Johnson TA, Lyra C, Karkman A, Stedtfeld RD, Tamminen M, Tiedje JM and Virta M. 2016. Aquaculture changes the profile of antibiotic resistance and mobile genetic element associated genes in Baltic Sea Sediments. FEMS Microbiology Ecology 92(4):1-7.

Negara KS. 2014. Analisis implementasi kebijakan penggunaan antibiotika rasional untuk mencegah resistensi antibiotika di RSUP Sanglah Denpasar: studi kasus infeksi Methicilin resistant Staphylococcus Aureus. Jurnal Administrasi Kebijakan Kesehatan 1(4):42-50.

Pal C, Palme-Bengtsson J, Kristiansson E and Larsson DGJ. 2016. The structure and diversity of human animal and environmental resistomes. Microbiome $4: 54$.

Peraturan Menteri Kesehatan Republik Indonesia Nomor 8 Tahun 2015 tentang program pengendalian resistensi antimikroba di rumah sakit

Peraturan Pemerintah Nomor 82 Tahun 2011 tentang pengelolaan kualitas air dan pengendalian pencemaran air.

Prigitano A, Romano L, Auxilia F, Castaldi S and Tortorano AM. 2017. Antibiotic resistance: Italian awareness survey 2016. Journal of Infection and Public Health 11(1):30-34.

Rather IA, Kim BC, Bajpai VK and Park YH. 2017. Self medication and antibiotic resistance: crisis, current challenges, and prevention. Saudi Journal of Biological Sciences 24:808-812.

Shark OC. 2005. Microbial source tracking: current technology and future direction. Applied and Environmental Microbiology 68(12):5796-5803.

Stoeckel DM. 2005. Selection and application of microbial source tracking tools for water-quality investigations. Collection of environmental data. USGS.

Tian S, Wang Z and Shang H. 2011. Study on the self-purification of Juma River. Enviromental Sciences 11:1328-1333.

World Bank. 2013. Downstream impacts of water pollution in the Upper Citarum River, West Java Indonesia. World Bank. Washington.

[WHO] World Health Organization. 2014. Antimicrobial resistance: global report on surveillance. WHO. France. 